Historic, archived document

Do not assume content reflects current scientific knowledge, policies, or practices. 

Louis Chretien. A fine Rex Begonia of exceedingly beautiful coloring, and a very high lustre, like changeable silk. Flowers large, and of a beautiful pink shade, the zone very distinctly marked and of a soft rose color. Price, 20 cents.

Rex. (Sfreics) One of the most effective of its class, though the oldest variety. Of a beautiful metallic lustre, center and edge soft velvety green with broad silver zone terminating in the point.

Mme. Treyve. (Discolor Rex.) One of the upright growing varieties, but of the distinct form and texture of the true Rex. Narrow edge of brownish plum color about a very broad soft green zone.

Duchess of Brabant. One of the softest in color and texture; dark plım-green center and edge, with broad zone of silver shading into bright green; red stem

Grandis. Large leaf of silver lustre, with narrow dark edge. A strong grower.

Queen Victoria Solid silvery leaf, of crèpe-like texture, and reddish veins, and fluted reddish edge.

Mme. Allwardt. Smooth silvery leaf, with high lustre and narrow dark edge. A very satisfactory variety in growth.

Lord Palmerston. Broad light metallic zone, edge and center dark red, finely dotted over with silver.

Queen of Hanover. Leaf of very soft velvety texture, covered with red pile, center and edge of soft green veliet, the zone formed by tiny silver dots.

Golconde. One of the showiest; a broad irregular zone follows the form of the leaf, terminating in a point; edged with very dark green; red velvety stems.

Quadricolor. Center a good red, surrounded by silver white zone, banded with light, soft green, with a ruffled edge of bright red. Very beautiful

\section{FLOWERING BEGONIAS.}

If your window garden can accommodate only one plant, let it be one of the freest flowering and largest growing of this class; if you can grow a dozen sorts your delight will be increased twelve-fold. Give them a light soil, woods earth, some sharp sand, and rich loam; a lilll' old cow-yard soil may be used, if thoroughly decomposed, and will very much heighten the rich coloring of the leaves, but in too large quantities, or if fresh, it is very harmful. Do not allow the soil to become sodden (plenty of sand will prevent this), and do not give too much water. Begonias are not troubled with insects of any kind; only keep them free from dust. There is the greatest diversity in varieties; some sorts have five-pointed leaves a foot or eighteen inches across, while others have foliage as fine as a sweet briar.

Alba Picta. A perfectly distinct new variety. It is shrubby in habit, and of very compact growth, having long, slender, pointed leaves on short stems. The leaves are glossy green, thickly spotted with silvery white, the spots graduating in size from the center toward the margin. Foliage small and elegant The branches are upright, and gracefully curving 1i) cents

Argyrostigma Picta. A handsome, compact growing variety. Leaves smooth and glossy, a silvery green, dotted white, and the shape of the k'ubra leaves. Flowers lemon white, produced in corymbs. A magnificent pot plant. 10 cents each

Bruantii. By some grown under the name of Massiliensis. A very dwarf, compact grower, rarely attaining more than five inches in height. Color of flowers pure white; the flowers are produced in such quantities that they completely hide the beautiful foliage. Price, 10 cents.

Bruanti Elegans. Leaves small to medium in size, of fan shape, and so glossy they appear to have been triple varnished. Color a clear bright green. A very graceful shrubby shaped plant, bearing sprays of white bloom. 10 cents.

Bruanti Rosea. Quite as fine as Elegans, while the leaves are darker in color, with veins depressed. The flower is a fine rose color. An excellent variety. 10 cents.

Lobata Variegata. Medium size, smooth, long pointed, and prettily notched; lightly edged with red; body dark green, with silvery spots. Shrubby in habit. A very good sort. 10 cents.

Caroliniafolia. A large growing variety, with leaves palmate of the same form as the five-leaf Virginia Creeper. Glossy surface, of good green; underside covered with substance like white cotton. 20 cents.

Dr. Nachtigal. Flowers a tender rose color and very odorous - the only fragrant Begonia that we know. It has large deep green leaves, and is a strong, vigorous free-flowering variety, of upright growth. Very pretty. Price, 1ij cents.

Feastii. A low, spreading Begonia, with perfectly circular leaves, red beneath and dark glossy green above, and of heavy texture. After the style of Sanguinea, save shape of leaf, and being still dwarfer. Very pretty and ornanental. 15 cents

Metallica. A fine, erect-growing Begonia, with dark, rough leaves; tire surface is a lustrous bronzegreen; veins depressed and dark red. The depression of the veins givf:s the leaves a crape-like appearance. The leaf is triangular in form, much longer 
than wide. A free bloomer. The panicles of unopened buds are bright red, with surface like plush. When open the flower is waxy white. A friend in a farmhouse showed us a Metallica in one window, a Rubra in the other. They were in large pots, and each was over four feet high. A grown person could not reach around the Metallica. It was two years old, and had bloomed freely throughout the winter. A very fine variety. Price, 10 cents.

Goury. A smooth, small-leaved, erect variety; flowers pale pink. 10 cents.

Glaucophylla Scandens. Leaves dark silvery green, with lighter edge, long, pointed, and graceful. A pretty trailing variety that can be trained on a light support. A beautiful basket or shelf plant. Profusion of orange-colored flowers. 10 cents.

Manicata. A large leaved variety, surface smooth and bright green. The large panicles of pink flowers are borne high above the foliage. 10 cents.

McBethii. Of the Weltoniensis type, with very deeply indented leaves, which are fine and small. Shrubby in growth, and very free-flowering, being constant the year round. A fine summer bedding plant, if given a light soil and perfect shade; put it among your ferns. White flowers, waxy in texture, carried in panicles. Price, 10 cents.

Nigricans. Upright growing; color a dark red, overspread with a distinct silvery shade. Pink flowers. Very fine for pots, vases, or baskets, as it is free and bushy in growth. Price, 15 cents.

Incarnata. An erect growing variety, with narrow, sharp-pointed leaves, small, notched, and glossy The flower is medium-sized, and bright pink. Price, 10 cents.

Rubella. Belongs to the Ricinifolia section, having large, velvety, deeply-pointed leaves. The ribs are banded with purplish brown, while the ground is a pallid green, blotched with red. Price, 25 cents.

Richardsoni. Foliage finely cut and fern-like flowers pure white, very free. Price, 10 cents.

Semperflorens Gigantea Rosea. One of the best of the new Begonias. The following are its strong points: It is vigorous and erect-growing; one of the strongest. It has a very large flower, of a clear, definite cardinal red, the bud only exceeded in beauty by the open flower, which is borne on a strong, thick stem. The leaves are smooth and glossy, and attached closely to the main stem; both leaf and stem quite upright-growing, and forming a shrubby, round plant. It flowers continually from October to May, and is withal one of the most satisfactory plants in the whole family. Price, 35 cents.

Amelia Bruant. A wonder fully free growing Begonia, of sterling worth and gritat beauty. This has the habit of frequently blooming at the junction of the ribs of the leaf, and it imparts a novel appearance when exhibiting this peculiar character. However, this peculiarity is not fixed, for like the other varieties, it also flowers from the axil of the leaf. The plant is very compact in growth, forming a dense, well-proportioned bush. Flowers carmine rose, and produced in great abundance during the Winter and Spring months. We recommend this very highly to all who love good Begonias. Price, 35 cents each.

Ricinifolia. So called from its likeness to the Ricinus, or castor-oil plant. The leaf is very largewill average a foot or more in diameter - and is separated into seven or nine large points, carried on thick, heavy stems, eighteen inches or more in height ; color a rich green, with reddish markings; surface velvety. In bloom it is magnificent; the panicle, composed of great numbers of individual pink blooms, is lifted high and spray-like, quite clear of the foliage. One of the best for winter bloom, besides being ornamental in foliage. Price, 15 and 25 cents.

Hybrida Multiflora. Leaves exactly the size and shape of the brier roses. Habit upright, branches rising singly from the root. Flowers rosy pink. 10 cents.

Ric. Maculata. A very fine variety, with large, pointed leaves on heavy, tall stalks, like Ricinifolia, of velvety texture; a rich brown color, banded with pale green. It bears large sprays of pink flowers on long footstalks. 20 cents.

Rubra. If you only have one Begonia, let it be a Rubra, for it will prove a constant delight. It is so fast growing that it will in a year or two reach the top of your window, sending up heavy, stiff canes an inch in diameter, and rising beside them will grow strong, slender branches, gracefully drooping under heavy, waxen leaves and pendant panicles of coral-colored flowers as large as a hand. We have seen a medium-sized plant with more than twenty such panicles at a time. Among the individual flowers you will find three distinct forms growing side by side. One of the most wonderful plants within our knowledge. Price, 10 cents.

Rubra Alba. This is a "sport" from Begonia Rubra, having foliage similar, but more drooping, and with clusters of white flowers, not so free-flowering nor so vigorous in growth as the Rubra. Price, 10 cents.

Sanguinea. Leaves dark, reddish green, pointed, stiff, glossy, and smooth-edged; under side dark crimson. A spreading variety, neither trailing nor erect growing. Flowers white. Shows well on bracket. Price, 10 cents.

Sandersii. The stalks rise from a main root without side branches. Leaves small, smooth, pointed 
ovals. Each branch bears a cluster of drooping, scarlet, heart-shaped buds, which are very lasting Constant bloomer. Price, 10 cents

Semperflorens Elegans. This fine new variety attains a height of 12 or 14 inches, and is a compact mass of medium-sized, glossy, olive-green leaves. It is so free in bloom as to present the appearance of a fine bouquet; the flower is a rosy flesh color. shaded with bright rose, and enlivened with dense clusters of yellow anthers. It blooms continually, but is freest in the winter. Price, 33 cents.

Verschaffelti. Very tall and roloust, similar to Gilsoni, but less notched and pointed. Longstemmed pink flowers. A magnificent ornamentalleavel variety, which throws its flower stems is to 24 inches in height Blooms in the winter. Price, 25 cents.

Weltonierısis, After you have begun your cultivation of Begonias with a Rubra first, let $V_{i}$ itoniensis be second, then get as many more as you can afford. This is the most widely known of the species; if it were harder to grow, or more expensive, it would probably be more sought after. With the least possible trouble this plant can be grown into an object of surpassing beauty. The leaf is delicate green in poor soil, but enrich it with a little old rotted manure and heavy velvety shadings of black appear on the maple-like leaves, every branch bearing its delicate bunch of rosy pink bloom. May be

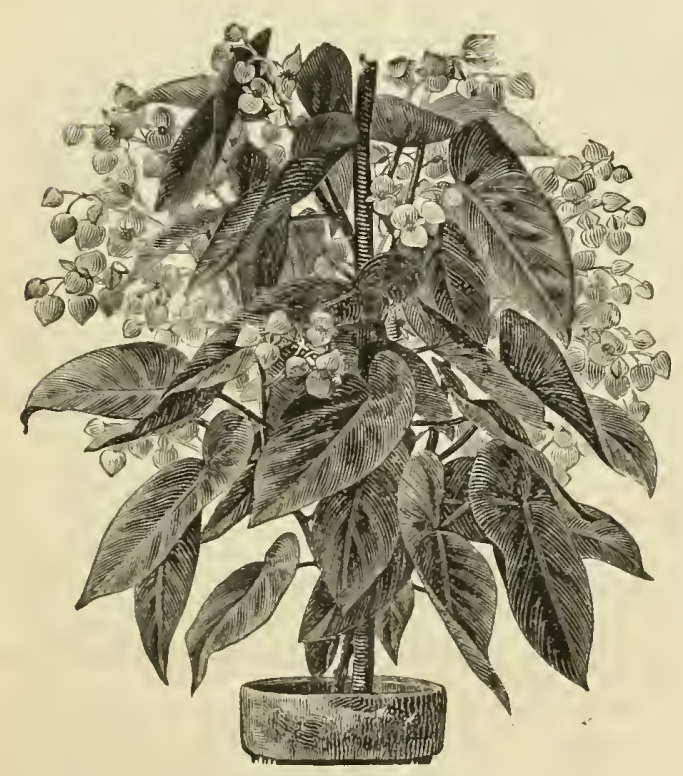

HEGIONIA IRUIBIRA. bedded in the Summer like McBethiz. Price, 10 cents.

Zebrina. The leaves are long and pointed, descending from a lobed shoulder; distinguished by the glistening silvery shading, the body being a very dark silky green. Price, 10 cents.

\section{TUBEROUS ROOTED BEGONIAS.}

Tuberous rooted Begonias are among the handsomest of our Summer blooming plants. They thrive finely when bedded out in a partial shade, and are objects of great beauty the entire Summer, rivalling the Geranium in purity, depth, and intense coloring. Not only are they good bedders, but do admirably grown in pots. We offer a splendid lot of bulbs, from one of the great Begonia specialists in France, which will reach here in November; these can be safely sent through the mails in the dry state. As soon as the bulb shows indications of starting, place in pots and transfer to open ground, after danger of frost is past. A light loam is best.

\begin{tabular}{|c|c|c|c|c|}
\hline Sing & & white $\ldots \ldots \ldots \ldots$ & 25. & $\begin{array}{l}\text { Doz. } \\
\$ 250\end{array}$ \\
\hline “' & “" & brilliant red....... & 25 & \\
\hline Doub & we & pure white.. & 35 & \\
\hline “ & $\because$ & bright rose..... & 50 & \\
\hline “ & “ & rich dark red. & 35 & \\
\hline '. & “ & bright yellow. . & 75 & \\
\hline
\end{tabular}

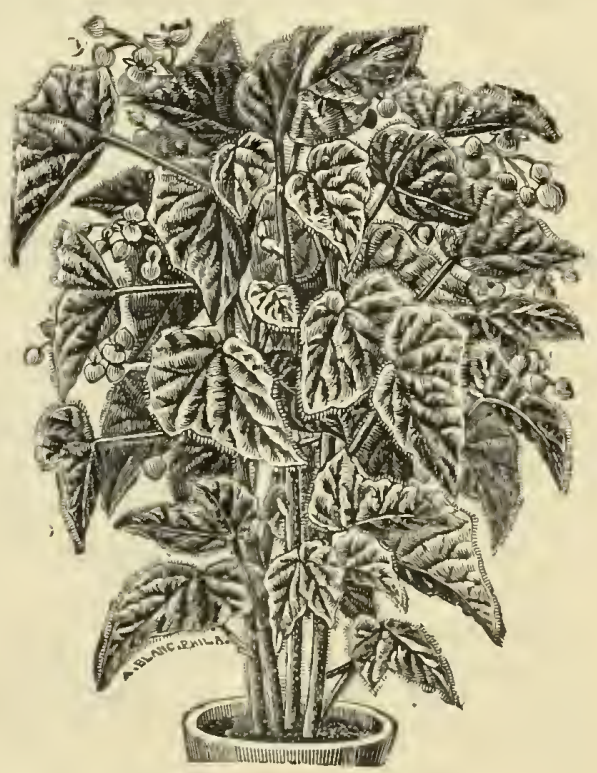

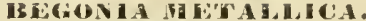




\section{$\cdots R O S F S$ \\ Flum the south and fon the Pavific Slope.}

\section{FOR THE WIN DOW OR CONSERVATORY.}

So many of our customers in the South and in the Pacific States, have written of their success with Fall-planted roses that we have prepared a nice stock for their special use, principally in three-inch pots, and well grown. The mild winters allow them to become quickly established, and they are ready to bloom very early in the new year.

For the window or conservatory we specially recommend as most suitable :

Perle des Jardines, yellow. Niphetos, pure white.

Edith Gifford, cream.

Marie Guillot, white.

C. Mermet, pink.

Pierre Guillot, red.

La France, silver pink.

Sunset, copper yellow.

M. Neil, yellow.

Mme. Watteville, pink and cream.

Keep the temperature low, except for sunlight, supply the foliage with moisture by spraying, but do not keep the soil sodden.

\section{New Teas and Hybrid Teas}

\section{OF THE PAST YEAR.}

Plants from pots, price 25 cents each, except where noted.

Viscountess Folkesione. H. T. One of the very largest and most double of roses; unsurpassed in freedom of bloom, and very remarkable for its keeping qualities. The flower is delicately tinted, almost white, showing a faint, creamy pink on the reverse of the petal. It is also deliciously fragrant.

Ye Primrose Dame. Very double, with petals beautifully curved; very free flowering; the outer petals are a soft but distinct canary color, the center a rich rosy salmon or apricot. The habit is somewhat like Niphetos.

Susanne Blanchet. Outer petals a clear flesh white, with deep flesh center; perfection itself in color, and charmingly beautiful ; in shape similar to certain varieties of the old Provence Rose.

Souv. de Victor Hugo. Bright china rose, with copper yellow center, ends of petals suffused with carmine. A charmingly beautiful combination of coloring.

Comtesse de Frigneuse. The buds are long and pointed, not unlike Niphetos in form, and of good size; the color is delicate canary yellow, with softer shade on inside of petal.

Meteor. H. T. A velvety red Everbloomer has long been demanded, and now we have it; not the satin finish and lighter red of Papa Gontier, but the 'deepest glowing crimson, as fine as a Hybrid; flower of medium size, very double, and petals slightly recurving; a beautiful open rose, a free bloomer, and promising well as a pot rose. It has no tinge of violet or purple to mar its beauty (as Bennett often has), it does not come minus a stem, as Duke of Connaught so often does, but promises to be a reliable dark red everbloomer, free from bad qualities.

Puritan. H. T. We could almost characterize this as an everblooming Merveille de Lyon. The foliage, the calyx, the bloom, would all place it among the H. P.s, but it is an undeniable everbloomer. The flower is of grand size, of the purest ivory white, very double, and set in abundant calyx foliage of deep green. It throws up heavy thorny canes, and carries a profusion of dark, large leafage. Its keeping qualities may be inferred when cut blooms crossed the Atlantic in good condition. Its greatest beauty is as an open rose. Already very popular.

Mme. Schwaller. H. T. Like Puritan, this rose has the strong, firm growth of the H. P.s, the same form and finish of flower, being especially beautiful when full grown. It is very free in bloom and has the fragrance of La France. The color is a bright 
rosy flesh, paler at the base of the petals, and deepening on the edges. Apt to come in clusters, which are excellent for cutting.

Mme. Etienne. One of the very finest of clear pink Tea Roses; the form of the flower is quite similar to that of Beatrice; that is, the petals recurve, giving it the shape of a Camelia. The texture is heavy, and the color is a warm, yet delicate pink, slightly deeper on the edge of the petal. A very beautiful variety, and freer in bloom than C. Mermet. This rose is styled the Dwarf Mermet by the French growers. It gives every promise of being a splendid rose.

Princess Beatrice. A pure Tea, of strong grow ing halit; heavy foliage, coloriug deeply after the style of Perle; flower stems stift and upright, and bright red, carrying large buds of exquisite color; outer petals varying from canary to golden yellow, edged lightly with bright rose color; from its first opening the petals roll their edges backward, displaying the bright apricot center. The open rose is exquisitely beautiful, very double, and lasting well when cut. Strongly tea scented. We feel sure it will prove a fine garden rose.

Chateau des Bergeries. Light canary, center darker yellow. Globular flowers; free blooming.

Duchess Bragance. Light canary yellow, paler on the edges.

Lady Zoe Brougham. Bright tawny yellow, after the style of $M a$ Capucine, but more double aud of better form. This has bloomed finely for us, aud we were tempted to put it among the twelve best.

Mile. C. Perreau. Bright rose, often coming very pale rose; vigorous grower, finely shaped buds. A seedling from Sou. d'un Ami.

Mme. H. Defresne. Beautiful citron yellow, with coppery reflex. Strong growing and free blooming.

Elizabeth Grammont. Bright rose, base of petals coppery yellow. A lovely open rose, and quite constant in bloom.

Dr. Grill. Coppery yellow, with a fawny rose reflex, back of the petals shaded china rose; an entirely new color. Large, well-formed flowers, of good shape. A vigorous, healthy grower, and very free in bloom. (Raiser's description.)

Vicomtess de Wautier. Beautiful rose, color, petals tinted yellow on the outside and rosy white inside. The center a deep rose, produciug a charming effect. Large, full, vigorous, and exceedingly free in bloom. (Raiser's description.)

Marie Lambert. Pure white; a seedling from Mme. Bravy, and even more vigorous. Has been called the White Hermosa, which it resembles in form and freedom of bloom.
Princess Hohenzollern. Another fine red Tea, a seedling from Papa Gontier; quite similar to it

Madam Scipion Cochet. A charmingly beautiful new Tea Rose of more than usual merit. Color, a soft primrose yellow, with rose shadings. Deliciously sweet scented and very unique in the size and shape of its buds As this belongs to the Countess la Barthe section, its freedom of bloom is at once settled

\section{Tea and H. T. Roses.} STANDARD SORTS.

From 3 -inch pots. Price, 15 cents (except where noted); $\$ 1.50$ per dozen.

Antoine Verdier. Flowers large and well formed, of a fine dark rose color, with a well defined line of silver on the edges of the petals. Vigorous and freeblooming. As hardy as La France, and a wonderful rose for autumn blooming. This is one of the very finest bedding roses known. Hardy in the North, and valuable on that account. Hybrid Tea.

Souvenir de la Malmaison. A noble rose; the flower is extremely large, quartered, and double to the center ; color flesh-white, clear and fresh. Has been considered a grand rose for thirty years. Its great beauty in the Fall makes it the finest of all roses at that season.

Francisca Kruger. The striking color of this handsome rose places it at once in the front as a bud producer in the open air. It is closely allied to Catherine Mermet, in everything save color, and in its shading of deep copper yellow it stands unique and distinct from all others. The flower, when opened, is of good size and very symmetrical. Very many who purchased this rose last year have written in praise of it. One of the finest roses to plant in masses and clumps. Try a dozen plants of this in a bed, and delight yourself and friends.

Catherine Mermet. One of the very finest roses grown, in every sense of the word, and a rose that pleases everyone. It has of late years disputed the right of La France to reign among pink roses, and well it may, for it combines every good quality found in the perfect bud and bloom. Its flowers are not only large, but almost faultless in form in every stage of development. The color is pure silvery rose, illumined at the base of petals with yellow. We recommend this variety for general planting, knowing it will please

Cornelia Cook. Long considered the best everblooming white, except Niphetos. It is a beautiful creamy white; buds of immense size, and very double; sometimes does not open well, which is its weak point, but a magnificent flower when well grown, and very sweet scented. A good grower. 


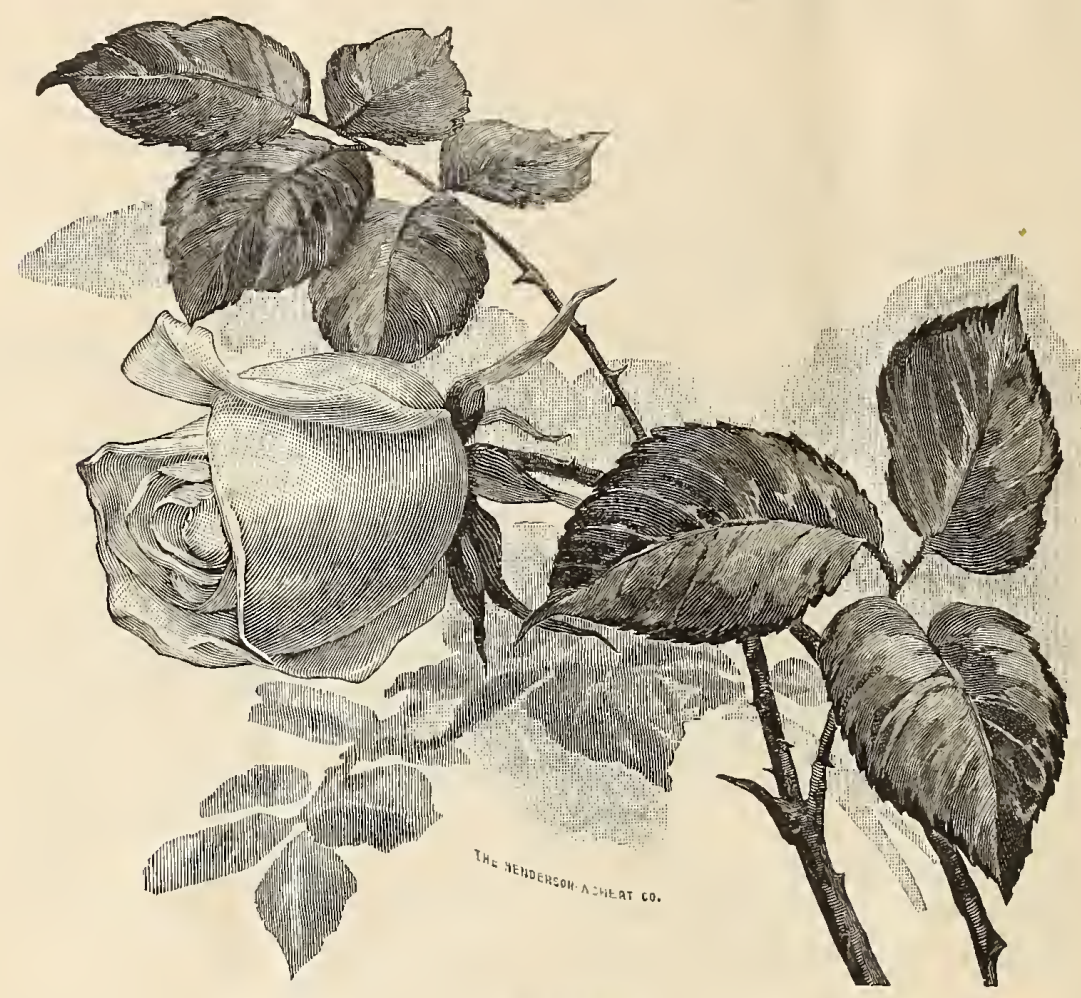

SUNSE'T

Comtesse Riza du Parc. Color coppery rose, tinged with soft violet crimson. A distinct and valuable rose. The flowers are somewhat larger than Comtesse la Barthe, but not so freely produced.

Etoile de Lyon. Our illustration of this notable rose does scant justice to its superb form. It is considered one of the finest yellow bedding roses for outside planting. It is, moreover, one of the hardiest roses in the Tea section. It blooms freely, and every flower is a gem. As fine as Neil.

Coquette de Lyon. No rose like it for freedom of bloom. The plant is a fine grower, and carries numbers of flowers on every shoot. A fine yellow rose, large, not at all formal, but very attractive. Called the yellow Hermosa, from its free-flowering character.

Devoniensis. On account of its whiteness and sweetness often called the magnolia rose. Creamy white, delicately flushed in the center with pink: One of the most fragrant roses, and a favorite of long standing.

La Nuance. A beautiful rose, good size, very double; color salmon rose, tinged with coppery yellow. A very elegant and distinct sort.

La Princess Vera. A vigorous rose; flowers very large and full, perfectly double; color creamy white; outer petals copper yellow. It produces large, pointed buds, very double, deliciously fragrant.

Bon Silene. Noted for the size and beauty of its buds; color deep rose; not double when full blown; highly esteemed for its rich color and beautifully formed bud; invaluable for cutting and for floral decoration. A valuable old acquaintance.

Homer. Beautifully folded buds of a bright, fresh rose color, and often peculiarly spotted with white. Hardy, free, and vigorous. "In the Autumn its colors are marbled on with exquisite art, until it vies with the most beautiful of all our roses, and has at times run hard and even beaten the very best at our great rose shows."-Garden.

La France. H. T. We give this the first place, - the Queen of all the roses. Accounts have come to us from all quarters describing the great profusion of its bloom from June till frost.

For the few who do not already know it, we will say it is of extra size, extra double, and of superb form. No rose can surpass it in delicate coloring silvery rose shades, with pink; it has a satin sheen over all its petals. It is universally regarded as the most beautiful and useful of roses, for it is hardy beyond question; it blooms only too much for its 
own good; the flower is large, beautifully built, endures for a great length of time, is finely colored, and fragrant in the highest degree. Always popular in this country, it is now the rage, and La France roses are the elegant thing for wearing and decoration in the Eastern cities, and, like the taste for Mermets, it is destined to become permanent.

Grace Darling. A large, full flower, handsomest when perfectly open. Color the richest shade of carmine pink, a uniform and decided color, but never quite obscuring the ground of beautiful yellow upon which it rests. Price, 20 ceuts.

Mme. Falcot. Apricot yellow. An old rose, not superseded by a better variety. Flowers of medium size and fullness, but very beautiful in bud.

Mme. Welche. Au extra fine variety ; very large, double, and of beautiful rounded form. Color apricot jellow, very heavily shaded throughout the center of the flowers witl dark orange red, variable at times, frequently coming light canary, with deep shadings. The flowers are large, of good size and substance, and endure well after opening, giving the bush a handsome appearance. One of the very best Tea Roses. Owing to the great demand at all times, the rose is comparatively scarce and held at a high figure. Our stock this year warrants us in placing this grand rose at $1 . \bar{j}$ cents.

Miss Edith Gifford. Of fine vigorous growth, foliage similar to Perle des Jardines; flowers large, of heavy texture; very fine, both as bud and open flower. Color fresh white or cream, with very distinct light pink center.

Marechal Robert. A splendid rose, large, full, globular form; color pure white, faintly tinged and shaded with soft rosy-blush and pale lemon; the bud is fine, while the open rose is large, full and extremely beautiful. Fiue in Autumn and for forcing.

Marie Guillot. I'erfection in form; the flower is large and double to the center. Until the iutroduction of The Bride, this held first place among White Tea roses in purity of color, depth of petal and queenliness of shape. Grows well, and is healthy. One of the best out-door summer-blooming roses; an absolute pure white when fully open. In connection with this excellent variety, might be mentioned the fact that all the live Florists grow this by the hundred and thousand in the open ground, for its beautiful buds and flowers during Summer. IVe know of one Philadelphia firm who grew an acre of this variety alone, simply for its buds in Summer. This is a sufficient recommendation of its merits. It is the best white bedding rose we know of.

Niphetos. A snow white rose of immense size, the bud when full grown running from two to three inches in length; the standard for determining value of long-pointed buds by comparison. When half blown or fully open, it is positively startling by its size and purity. The foliage is beautiful, stems slender, and drooping under the weight of buds. An absolute necessity in a green house. To do well out of doors, it is necessary to have extra-sized plants. We grow two sizes of this rose; the usual size 15 cents, larger plants 30 cents.

Mme. Maurice Kuppenheim. Very fine, large, full flowers; beautiful pale yellow, lightly touched with pink and shaded bronzy carmine; varies greatly during the season, but is always beautiful whether darker or lighter shades predominate. Very sweet scented. One of the finest roses in the Tea section.

Mme. Lambard. This variety, as seen by us the past few years, is lacking in one certain point, and that an essential one : it carries too many poor buds. Out of a dozen or fifteen buds, one perfect one will develop. The color is variable; purplish rose, sometimes very red, the outer petals creamy. We shall continue to grow this variety, but in limited quantity.

Nathalie Imbert belongs to the semi-double section, and, like its class, is very free-flowering. The buds are of good shape, and of a most clear carminerose color. A very beautiful rose of 1885 .

Pierre Guillot. H. T. One of the finest and most valuable in the whole list; bright, dazzling crimson, passing to brilliant carmine; flowers large, very double and full, and highly scented; a healthy and vigorous grower, and a constant bloomer from June till frost. The outer petals are broad, round, and decidedly recurved, showing the short, closely-set inner petals. Among the few red everbloomers, this ranks very near the front, for it is double, without a tinge of a disagreeable shade, and always in bloom. We have a very large stock of it in nice plants.

Sombreuil. This magnificent variety has immense finely-formed flowers of beautiful white, tinged with delicate rose; buds large and full, blooming in clusters. A grand and beautiful rose when in full bloom. $20 \mathrm{cts}$.

Perle des Jardines. The one Tea rose which you positively can not afford to do without. It has absolutely no weak point, but is a perfect and popular rose. The color is faultless, whether the waxy petals show the rich cream tint of cool weather, or take on the richer golden shades which a warmer sun gives them. The form of the bud is rich, rounded, and luxuriant; it is only equaled in beauty by the open rose, which is full to the center and large. It is no shy, creeping plant, but is fairly riotous in growth, sending out quantities of beautiful foliage, thick, glossy, and dark, every branch being tipped with the dark reddish-maroon of the young shoots, and bearing itsi bud or cluster of buds high above the leaves. We sold during the past year as many Perles as of all other varieties taken together, which demonstrates its popularity. 
The Bride. The best pure ivory-white Tea Rose. The bloom is not finer than Niphetos, for that is impossible; but it is stronger growing, and will thrive where Niphetos would not do so well. Save in color, it is identical with Catherine Mermet, from which it is a "sport." The buds, which are of grand size, are carried high and erect on bright, smooth stems. A fine bunch of these buds, cut with long sprays of foliage, would grace any bride in her wedding robes. It has, however, one fault, which we are sorry to name: it "pinks" in very hot weather; that is, the outer petals take on a pale flush. Nevertheless, except in unusually hot, dry summers, it is unsurpassed for purity of whiteness and for form and size.

Souvenir Isabell Nabonnand. Light fawn color; very large, glooular buds; strong grower and free bloomer. A superior and distinct variety.

Souvenir de Therese Levet. A very beautiful rose; a genuine red Tea; pure, clear crimson, assuming a slight cast of purple as the flower ages. The bloom bears a considerable resemblance to Catherine Mermet in form; each petal shows at the center of its margin a decided point, which gives the flower a clear-cut appear. ance. Its odor is powerful and delicious. 20 cents.

Sunset is a "sport" from that grand variety, Perle des Jardines, which it strongly resembles, except in color. The flowers are of large size, fine, full form, very double, and deliciously perfumed. The color is a remarkable shade of rich, golden amber, elegantly tinged and shaded with dark, ruddy copper, intensely beautiful, and resembling in color a splendid "after glow." Sunset is a constant and profuse bloomer, and, taken altogether, is probably one of the finest roses recently introduced. It is particularly valuable for forcing and growing in conservatories.

Katie Metchersky. Belongs to the Mme. Falcot type; beautiful long pointed buds, of the very finest form; color soft creamy yellow, with carmine and bright silvery shadings. A veritable beauty. Foliage small and fine, but very dense; of excellent habit and of rapid growth.

W. F. Bennett. Undoubtedly the best red ForcING rose in existence, though closely followed by Papa Gontier. If you live near any large city, you have doubtless seen Bennett in its glory at some good greenhouse. A cluster of good buds of it is not soon forgotten ; but there are few localities where it beds out satisfactorily, turning into a variety of dull colors with the sun, and opening quite single. 25 cents each.

\section{CLIMBING TEAS AND NOISETTES.}

I5 cents each, except where noted.

Cloth of Gold. Golden yellow; fragrant. One of the finest roses, but a shy bloomer.

Baron Sinety. Of Gloire de Dijon parentage climbing habit. Color deep yellow, with dark center. Of fine form and finish.

Celine Forestier. Color, fine canary yellow, with deeper shadings; finely formed flowers, and fragrant. Very free blooming. One of the best.

Gloire de Dijon. Our Southern friends are unbounded in their admiration of this fine rose, which is seen there in its fullest perfection, being quite hardy in their section, where it is used as a pillar rose. It is noted for the great size of its flowers, its delicate tea scent, and its exquisite shades of color, being a blending of amber, carmine, and cream. One of the finest roses on our list.

Marechal Neil. A beautiful deep sulphur-yellow; very full, large, and exceedingly fragrant. It is the finest yellow rose in existence. It has a climbing habit, and where it is allowed to grow until it attains a large size, as it will in a few years, it will yield thousands of beautiful flowers. A rose so famous as to need no description. Grown the world over for its golden-yellow flowers. We have a magnificent stock of this variety to offer again this year, running from 12 to 18 inches in height, a year or more old. These can not fail to give satisfaction. Price, Io and 20 cents, according to size.

Washington. Medium size, pure white, very double, blooms profusely in large clusters; a strong grower, suitable for trellis, etc. Quite hardy.

Lamarque. Flowers of medium size, borne in large clusters, which are the distinctive features of the rose. Established plants bear thousands of blossoms, pure white; double. It flowers in what a florist would call "crops," and is very beautiful in its seasons.

Solfaterre. Fine, clear, sulphur-yellow ; good form, large, full, and double; very sweet and good.

Waltham Climber, No. 3. The best and darkest of the three red seedlings of Gloire d' Dijon, an abundant bloomer, and especially free in the fall. A grand crimson flowered Autumn rose. Price, 25 cents. 


\section{PLANT DEPARTMENT.}

\section{Varieties Suitable for Winter Blooming.}

ABUTILONS (Flowering Maple.)

STANDARD SOR'TS.

ro cents each.

Arthur Belsham. Clear crimson.

A. Besson. Orange red, light veins.

King of Roses. Soft rose color. Very distinct.

Boule de Neige. Very best white.

Thompsonii Plena. Green and gold foliage, double flowers, lriglit orange and crimson.

Vexillarium Picta. A fine-leafed drooping variety; gold and green foliage; small pendant blooms. Fine for pot or vase culture.

\section{AGATHEA CELESTIS (Blue Daisy).}

Sky blue; small, smooth leaves of heavy texture. In bloom all the year. ro cents.

\section{ASPARAGUS TENUISSIMUS.}

Fine climber for the conservatory. Io cents.

\section{ACHANIA MALVAVISCUS.}

One of the very best house plants. Foliage soft green, cvery brancl tipped with scarlet flowers. Lasy to grow. 10 cents.

\section{DOUBLE SWEET ALYSSUM.}

Pure white. Invaluable for winter bloom. ro cents, 50 cents per dozen.

\section{ALOYSIA CITRIODORA (Lemon-Scented Ver- bena).}

Sweetest plant in cultivation. ro cents.

\section{ACALYPHA TRICOLOR.}

Fancy tropical plant of tree form; mottled with dark red, rose color, and bronze. 15 cents.

\section{AZALEAS.}

From 75 cents to $\$ 2.00$ each, according to size. (Smaller sizes will not bloom satisfactorily this season.)

PURE WhI'E.

Rose. RED. WhITE AND Rose.

The finest of conservatory plants. Keep cool and do not overwater.

\section{BOUVARDIAS.}

15 cents each.

Vreelandii, One of the best white varieties and a free winter bloomer.

Rosea Multiflora. Soft, pink color, in heavy clusters.

\section{CARNATIONS.}

Fielı grown for winter bloom. Give a night temperature of about $50^{\circ}$, and plenty of sunshine. Spray the foliage, but do not overwater the soil.

10, 15 , and 25 cents, according to size desired.

Buttercup. Yellow, penciled in red. Very large bloom.

Chester Pride. Pure white, penciled rosy carmine.

E. G. Hill. Large fiery crimson, fringed edge.

Grace Wilder. Soft, delicate pink.

Hinze's White. The standard white (opens a pale pink).

The Century. Glowing carmine.

W. W. Coles. S fft scarlet. Very fine.

$$
\text { NEW VARIE'TIES. }
$$

Silver Spray. Pure white and fringed; very sweet. Good plants, 25 cents.

Mrs. Cleveland. Silvery pink, notclied edges. A very fine variety. 25 cents.

Wm. Swayne and L. L. Lamborn, two white Carnations without tinge or stain of color. Flowers of immense size and very double; fringed and fragrant. Both raised by $\mathrm{Wm}$. Swayne, the difference consisting in form and habit of growth. Very profuse bloomers. Plants ready for bloom, 35 cents.

\section{COLEUS.}

Fancy varieties for pot culture, 10 cents.

Scarlet, ro cents.

$$
\text { CUPHEA (Cigar Plant). }
$$

CAMEL IA JAPONICA.

Double White, 50 cents to $\$ \mathbf{I} .50$, according to size. Choice colors, 50 cents to $\$ \mathbf{1} .50$, according to size. 


\section{CHRYSANTHEMUMS.}

Prices ranging from Io cents (small plants), to 25,50 , and 75 cents, according to size. These larger plants by express only. See Spring Catalogue for full descriptions.

$$
\text { ALL LARGE FLOWERED VARIETIES. }
$$

A. Warne. Incurved, white.

Blanche Coles. (Single.) Like an ox-eye daisy.

Culling fordii. Recurved, brilliant crimson.

Christmas Eve. Very large, feathery white.

Diana. Pure white, quilled.

F. L. Harris. Large, cinnamon red.

Frank Wilcox. Golden amber and bronze.

Golden Prince. Fine primrose yellow.

Grandiflorum. Very large, golden yellow.

Jennie Murkland. Yellow, apricut, and rose.

Jno. M. Hughes. Silvery Pink.

King of Crimsons. Globular, crimson.

Lord Byron. Orange, tipped red.

Moonlight. Ribbon petals, pure white.

Mrs. Mason. Odd shade of rosy pink.

Mrs. Langtry. (50 cents and \$1.oo.) Snow white, broad petals.

Mrs. George Bullock. Pure white, incurved.

Mrs. C. H. Wheeler. Orange, red center.

M. Wm. Holmes. Amaranth, reverse silver.

Mrs. J. B. Wilson. Ivory white, extra fine.

Marsa. Rose colored, white center.

M. Neville. Salmon, passing to rose,

M. Norman Davis. Rosy carmine, lilac shadings.

Osiris. Violet, pointed gold.

Puritan. Silvery white, very large.

Robt. Bottomly. Very broad petals, pure white. Syringa. Beautiful soft lilac.

Source d'Or. Gold shading to brown, needle petals.

Tokio. Cinnamon red and yellow.
Theodora. Salmon ros

Timbal d'Argent. Anemone center, broad ray of outer petals, pure white, perfectly distinct.

\section{FERNS.}

Pteris Argyrea. Silver fern. 20 cents.

Pteris Tremula. Finest growing for house. Io cts.

Nephrolepsis Cristata. Frilled or crested. $20 \mathrm{cts}$.

\section{FICUS (Rubber Plant).}

Elastica. Best known. 35 cents.

Lancifolia. Leaves like an Oleander. 35 cents.

FARFUGIUM GRANDE.

25 cents cach.

\section{GERANIUMS.}

Standard sorts of Double, Single, Scented. All fine varieties, pot grown, Io cents each; $\$ \mathrm{l} .00$ per dozen.

Bruanti. I 5 cents; $\$ 1.50$ per dozen.

\section{JASMINE GRANDIFLORUM.}

Large Starry Jasmine, Io cents.

\section{LANTANAS}

In variety. Io cents.

Io cents.

\section{WHITE OXALIS.}

PARIS DAISY.

White ray of petals about a golden disk. Io cents.

PANDANAS UTILIS (Screw Pine). 3-inch pots. 25 cents.

DOUBLE PETUNIAS.

Pure white and blotched. Io cents.

SMILAX.

ro cents.

\section{SEEDS FOR FALL SOWING}

\section{OR, EARLY IN JANUARY.}

\section{CENTAUREA GYMNOCARPA (Dusty Miller).}

The best white-leaved bedding-plant for summer effect. Use in lines with dwarf Cockscomb.

Beautiful white fern-like leaves; very valuable for white lines in ribbon planting, or for single specimen plants. 10 cents.

\section{COBEA SCANDENS.}

Large bell-shaped purple Iwers, of great sub stance. Cover lightly with sul and use a glass cover to start them. No handsomer climber can be found. 10 cents.

\section{COLEUS.}

Choicest new sorts, mixed. A superb stock which will produce magnificent varieties. 35 cents.

\section{CAMPANULA (Canterbury Bell).}

A lovely old-fashioned flower. Sow out of doors this fall for bloom next year.

Single white, 5 cents. Single mixed, 5 cents.

Double mixed, 10 cents. Single blue, 5 cents.

\section{CELOSIA, or COCKSCOMB.}

Start early in the house, and transplant the last of May. Give them a rich soil. One of the most beau- 